\title{
CONDITIONS OF TOURISM DEVELOPMENT IN POLISH VOIVODSHIPS
}

\section{BOŻENA RADKOWSKA, ${ }^{1}$ KRZYSZTOF ŁOPACIŃSKI ${ }^{2}$}

\author{
Warsaw School of Tourism and Hospitality Management, POLAND \\ 1 e-mail: bozradek@gmail.com \\ 2 e-mail: k.lopacinski@intur.com.pl
}

$\begin{array}{ll}\text { RECEIVED } & \text { 15 March } 2017 \\ \text { ACCEPTED } & \text { 12 June } 2017 \\ \text { JEL } & \\ \text { CLASSIFICATION } & \text { L84, C10 }\end{array}$

KEYWORDS | Tourism Competitiveness Index, tourism competitiveness rankings, tourism competitiveness of Poland and of voivodships

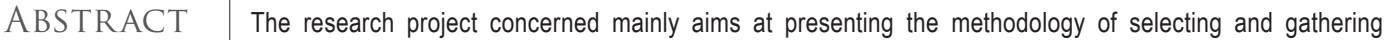
indicators describing tourism development at the national and regional levels and at discussing selected indicators gathered for individual voivodships in Poland.

It presents the structure of the Travel \& Tourism Competitiveness Index developed and computed for the World Economic Forum as well as the index results and components for Poland. The 2015 TTCl for Poland was 4.08, ranking Poland $47^{\text {th }}$ among the 141 countries covered.

The second part presents the assumptions of studies of the competitiveness of the sixteen Polish voivodships based on a set of indicators designed at the Institute of Tourism in Warsaw in 2004. The values of specific indicators for particular voivodships have been presented in the reports entitled Turystyka Polska. Układ regionalny since 2004. The article also contains examples of tables from the 2015 report.

Finally, the article presents the ranking of voivodships according to the value of the overall Tourism Competitiveness Index developed on the basis of eight sub-indices.

\section{Introduction}

The research project concerned mainly aims at presenting the methodology of selecting and gathering indicators describing the regional development of broader tourism and at discussing selected indicators gathered for individual voivodships in Poland. 
It must be emphasised that the fundamental objective of creating a system of indices and their standardisation at the international level is to produce various rankings. In our index analysis, we focus on selecting measurable indicators necessary to design and, subsequently, evaluate the implementation of multiannual and annual tourism development programmes in specific voivodships in Poland.

The system of creating standardised indices is a widely recognised tool for producing various rankings mostly aimed to assess movements in the positions of the entities concerned (countries/regions/cities). Opponents to standardised indices usually point to excessive diversity of particular entities. They also stress enormous subjectivity in the selection of specific non-measurable indices as well as a frequent lack of objectivity in the arbitrary specification of values of indicators hard to measure. It is indicated that it is difficult to justify combining significantly biased indices (e.g. a subjective assessment of the legal system in a country) with those characterised by accuracy (the surface area of a country). Therefore, especially for territorial units with indices hard to measure, most specialists tend to create time series for particular and relatively easily measured indices without aggregation, assuming that qualitative analysis will lead to correct and well-grounded conclusions, useful in economic and business practice.

Additionally, in the selection of indices considered for analyses it is frequently more important to be able to gather numerical data or to choose indices for which there are well-formulated methods of estimating their numerical values.

\section{Composite indices of the competitiveness performance of countries according to the WEF}

When assessing conditions of tourism development in a region and the impact of tourism on the regional economy, it is worth drawing on a most comprehensive list of indicators used by the authors of annual reports prepared for the World Economic Forum in Geneva for the purpose of presenting rankings of the competitiveness performance of individual countries.

Competitiveness is defined as the set of institutions, policies, and factors that determine the level of productivity of an economy, which in turn sets the level of prosperity that the country can earn.

The Global Competitiveness Index combines 114 indicators that capture concepts that matter for productivity. These indicators are grouped into 12 pillars: institutions, infrastructure, macroeconomic environment, health and primary education, higher education and training, goods market efficiency, labor market efficiency, financial market development, technological readiness, market size, business sophistication, and innovation (Schwab, 2015).

Let us now describe the place of Polish economy in WEF ranking.

According to The Global Competitiveness Index 2015-2016 ranking published by the World Economic Forum in The Global Competitiveness Report 2015-2016 (Schwab, 2015), Poland's economy ranks 41 ${ }^{\text {st }}$ among the 140 countries covered, with the overall score of 4.49 (for the top and poorest performers, Switzerland and Guinea, the respective indices were 5.76 and 2.84 ).

The overall index was calculated on the basis of three sub-indices - Basic requirements, Efficiency enhancers and Innovation and sophistication factors - each of which was composed of several pillars (a total of 14). Put rather simply, it may be assumed that the values taken by the fourteen pillars constitute an assessment of conditions indicating the position of the Polish economy in the modern world.

With regard to our investigation of tourism development conditions, in selected areas it may be methodologically important to take account of another composite index, also prepared by the World Economic Forum and published 
in The Travel \& Tourism Competitiveness Report 2015 (The Travel \& Tourism..., 2015), i.e. the Travel \& Tourism Competitiveness Index 2015. The index in question is composed of the following: 4 sub-indices, 14 pillars and 90 individual indicators.

Sub-index: Enabling Environment:

1. Business Environment (12 indicators).

2. Safety and Security (5 indicators).

3. Health and Hygiene (6 indicators).

4. Human Resources and Labour Market (9 indicators).

5. ICT Readiness (8 indicators).

Sub-index: T\&T Policy and Enabling Conditions:

6. Prioritisation of Travel and Tourism (6 indicators).

7. International Openness ( 3 indicators).

8. Price Competitiveness (4 indicators).

9. Environmental Sustainability (10 indicators).

Sub-index: Infrastructure:

10. Air Transport Infrastructure (6 indicators).

11. Ground and Port Infrastructure (7 indicators).

12. Tourist Service Infrastructure (4 indicators).

Sub-index: Natural and Cultural Resources:

13. Natural Resources (5 indicators).

14. Cultural Resources and Business Travel (5 indicators).

The Survey data is derived from responses to the World Economic Forum's Executive Opinion Survey and range in value from 1 to 7 . Hard data were collected from various sources. Hard data indicators used in the TTCI are normalized to a 1-to-7 scale in order to align them with the Executive Opinion Survey's results.1

The standard formula for converting each hard data indicator to the 1-to-7 scale

$$
6 \times \frac{\text { country score }- \text { sample minimum }}{\text { sample maximum }- \text { sample minimum }}+1 \text {. }
$$

The sample minimum and sample maximum are the lowest and highest scores of the overall sample, respectively. For those hard data indicators for which a higher value indicates a worse outcome (e.g. fuel price levels), we rely on a normalization formula that, in addition to converting the series to a 1-to-7 scale, reverses it, so that 1 and 7 still correspond to the worst and best, respectively:

$$
-6 \times \frac{\text { country score }- \text { sample minimum }}{\text { sample maximum }- \text { sample minimum }}+7 \text {. }
$$

Each of the pillars has been calculated as an un-weighted average of the individual component variables.

The subindexes are then calculated as un-weighted averages of the included pillars. In the case of the Human Resources and Labour Market pillar, which is, itself, composed of two subpillars (Qualification of the labour force and Labour market), the overall pillar is the un-weighted average of the two subpillars (Schwab, 2015). 
Calculated on the basis of the 90 indicators, the overall 2015 Travel \& Tourism Competitiveness Index for Poland was 4.08, making Poland $47^{\text {th }}$ among the 141 countries covered (it ranged from 5.31 obtained by Spain, the top performer, to 2.43 for the lowest ranking Chad).

In 2015, the authors of the above-mentioned report mainly focused on analysing the responses of the Travel and Tourism (T\&T) sector to health, security and economic shocks experienced over recent decades by the world economy. It was assumed that a strong and resilient T\&T sector was crucial for job creation and economic growth in both advanced economies and developing countries.

The report emphasises that the indicators particularly advantageous for Poland are those in which Poland obtained top or high ranks. Those are as follows:

- index of terrorism incidence (1),

- access to improved drinking water (\% pop.) (1),

- HIV prevalence (\% pop.),

- no. of regional trade agreements in force (1),

- hotel price index (us\$) (4),

- no. of environmental treaty ratifications ( $0-27$ best) (4),

- railroad density (km/surface area) (10),

- comprehensiveness of T\&T data (0-120 best) (10),

- hospital beds per 10,000 pop. (11),

- construction permits cost (\%) (11),

- total protected areas (\% total territorial area) (11),

- no. of World Heritage cultural sites (15).

In general, the pillars (groups of indicators) with the highest ranks include: Health and Hygiene (25 $5^{\text {th }}$ place), International Openness ( $26^{\text {th }}$ place), Environmental Sustainability ( $28^{\text {th }}$ place) as well as Safety and Security $\left(35^{\text {th }}\right.$ place).

The indicators having a considerable downward effect on Poland's position were those where Poland ranked low. Those are as follows:

- extension of business trips recommended (135),

- government prioritisation of T\&T industry (132),

- particulate matter (2.5) concentration ( $\mu \mathrm{g} / \mathrm{m} 3)$ (130),

- efficiency of legal framework in settling disputes (117),

- no. of days to start a business (112),

- sustainability of T\&T development (110),

- labour and contributions tax rate (\% profit) (110),

- hiring and firing practices (109),

- airport density per million urban pop. (109).

The lowest ranking pillars (groups of indicators) include: Prioritisation of Travel \& Tourism (99), Business Environment (77), Air Transport Infrastructure (73) and Tourist Service Infrastructure (66).

Obviously, in their assessment of competitiveness the authors of the report also took account of a number of absolute values (Travel \& Tourism Key Indicators and Economic Impact) such as: Poland's surface area and 
population, GDP and GDP per capita, international tourist arrivals in Poland and international tourism receipts as well as the share of the travel and tourism industry in the national economy and in employment.

\section{The system of indicators of tourism development in voivodships according to the Institute of Tourism}

In 2003, for the needs of the central government and regional (voivodship) authorities, the Institute of Tourism designed a set of and gathering methodology for indicators describing the development of broader tourism in individual voivodships (Borne-Januła, Byszewska-Dawidek, Kulesza, Legienis, Radkowska, 2003).

The main objective of the selection of indicators was to provide information necessary in the preparation of tourism development strategies for voivodships and in ongoing assessments of the current situation in the tourism industry and related sectors. It was also important to ensure full comparability of information in particular voivodships.

In addition, a significant assumption was to make the maximum use of information collected in various databases by the Central Statistical Office (Główny Urząd Statystyczny - GUS) and of the results of surveys carried out by the Institute of Tourism and commissioned by the department of tourism.

Since 2003, the set of indicators for three consecutive years prepared on an annual basis for marshal offices was supplemented with brief descriptions of tourism in all the voivodships and with a comparative analysis of the level and structure of tourism-related expenditure from the budgets of marshal offices. The first report covering 2001-2003 data, Turystyka polska w 2003 roku. Układ regionalny, was published in 2004 and the structure of subsequent editions remained virtually unchanged until 2015.

The set of indicators with descriptions adopted in 2004 and applicable until 2015 included the following groups:

1. Characteristics of accommodation facilities: the number and regional distribution of collective tourist accommodation establishments, hotels and similar establishments (hotels, motels, boarding houses), hotels by category, other collective tourist accommodation establishments (other than hotels, motels or boarding houses), camp-sites and holiday centres, individual tourist accommodation establishments accommodation at rural tourism holdings.

2. Other aspects of services supplied to tourists:
a) All travel agencies and travel agencies broken down into tour operators and intermediaries;
b) The length of tourist trails.

3. Air transport, cultural and environmental protection establishments:
a) Airports and passenger service at airports;
b) Museums and visitors to museums and museum exhibitions;
c) National parks - the area and number of visitors.

4. Tourists at collective accommodation establishments (the number of guests and overnight stays, also of foreign tourists, and foreign tourists staying at accommodation establishments by group of countries).

5. Domestic tourist traffic and foreign tourist arrivals:
a) The total number of domestic tourist arrivals in destinations located in the voivodships and broken down into long-stay ( 5 or more days) and short-stay ( 2 to 4 days) tourists;
b) The number of foreign tourist arrivals and the composition of arrivals by group of countries;
c) Expenditure of foreign tourists (average expenditure per person and per day of stay per person in USD).

6. Level and structure of tourism-related government expenditure from budgets of marshal offices. 
For each indicator, rankings of voivodships in particular years were prepared, in order to illustrate the dynamics of change and to allow voivodship administrations to carry out comparisons between voivodships.

The method of presenting individual indicators is shown in two tables containing the following information:

- the number of travel agencies registered in particular voivodships, with a ranking of voivodships,

- the number of accommodation establishments in particular voivodships, with a ranking of voivodships.

Similar tables were prepared for a total of 27 indicators. Furthermore, the level and structure of tourism-related expenditure in budgets of marshal offices (a total of 4 indicators) were presented.

As already mentioned, the values of specific indicators for selected voivodships can be presented as time series for the whole period covered. Such a graphical presentation of the number of visitors to the Pomorskie voivodship is exemplified in Figure 1. It is worth pointing out that the values of this indicator in specific years were estimated on the basis of surveys of foreign tourists visiting Poland carried out on an annual basis at border crossings.

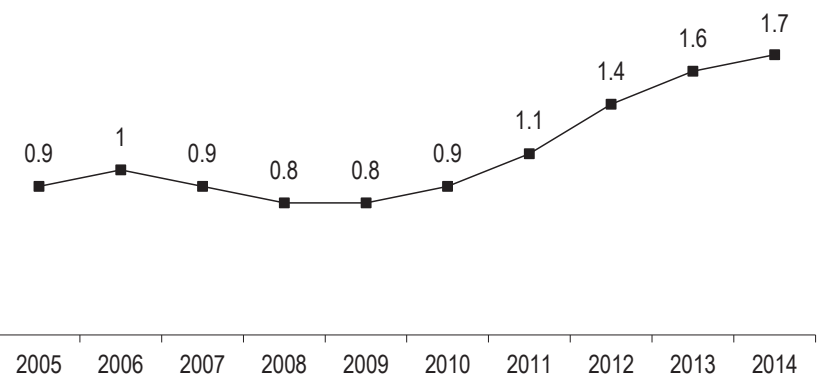

Figure 1. The number of foreign tourists in the Pomorskie voivodship (million)

Source: estimates by the Institute of Tourism based on surveys.

As in the case of countries, eight indicators (sub-indices) served to develop a composite tourism competitiveness index and ranking of individual voivodships. The sub-indices were as follows:

- the number of bed-places in accommodation establishments,

- the number of travel agencies,

- the length of tourist trails,

- the number of visitors to museums,

- the number of tourists staying at accommodation establishments,

- the number of domestic tourists,

- the number of foreign tourists,

- average expenditure of a foreign tourist.

Normalization of the value of chosen indicators shall be done according to the formula below (value of each indicator is between 0 and 1). For eight indicators normalized values were calculated specifying their ranks of the same time

$$
\frac{\text { Voivodship score }- \text { sample minimum }}{\text { Sample maximum }- \text { sample minimum }}=\text { Indicator value for voivodship. }
$$


Table 1. Example values, absolute ranks and normalized sub-indices values: number of bed-places in accommodation and number of travel agencies in 2015

\begin{tabular}{|c|c|c|c|c|c|c|}
\hline \multirow[b]{2}{*}{ Voivodship } & \multicolumn{3}{|c|}{ Bed-places in accommodation } & \multicolumn{3}{|c|}{ Travel agencies } \\
\hline & $\begin{array}{c}\text { number } \\
\text { of bed-places }\end{array}$ & ranking & indicator value & $\begin{array}{c}\text { number } \\
\text { of agencies }\end{array}$ & ranking & indicator value \\
\hline Dolnoślaskie - Lower Silesia Province & 60,147 & 4 & 0.55 & 329 & 4 & 0.35 \\
\hline \multicolumn{7}{|l|}{ Kujawsko-pomorskie - Kujawy-Pomerania } \\
\hline Province & 28,515 & 9 & 0.21 & 108 & 12 & 0.06 \\
\hline Lubelskie - Lublin Province & 21,848 & 12 & 0.13 & 133 & 10 & 0.09 \\
\hline Lubuskie - Lubuskie Province & 18,570 & 13 & 0.10 & 59 & 14 & 0.00 \\
\hline Łódzkie - Łódź Province & 23,128 & 11 & 0.15 & 200 & 7 & 0.18 \\
\hline Małopolskie - Małopolska Province & 90,304 & 3 & 0.88 & 511 & 3 & 0.58 \\
\hline Mazowieckie - Mazovia Province & 48,982 & 5 & 0.43 & 838 & 1 & 1.00 \\
\hline Opolskie - Opole Province & 9,401 & 16 & 0.00 & 73 & 15 & 0.02 \\
\hline Podkarpackie - Podkarpacie Province & 28,711 & 10 & 0.21 & 137 & 9 & 0.10 \\
\hline Podlaskie - Podlasie Province & 13,465 & 15 & 0.04 & 87 & 13 & 0.04 \\
\hline Pomorskie - Pomerania Province & 101,739 & 2 & 1.00 & 291 & 5 & 0.30 \\
\hline Śląskie - Silesia Province & 45,884 & 6 & 0.40 & 518 & 2 & 0.59 \\
\hline Świętokrzyskie - Świętokrzyskie Province & 16,101 & 14 & 0.07 & 74 & 14 & 0.02 \\
\hline \multicolumn{7}{|l|}{ Warmińsko-mazurskie - Warmia-Masuria } \\
\hline Province & 40,022 & 8 & 0.33 & 120 & 9 & 0.08 \\
\hline Wielkopolskie - Wielkopolska Province & 42,854 & 7 & 0.36 & 291 & 6 & 0.30 \\
\hline \multicolumn{7}{|l|}{ Zachodniopomorskie - West Pomerania } \\
\hline Province & 120,603 & 1 & 1.20 & 164 & 8 & 0.13 \\
\hline
\end{tabular}

Source: "Turystyka w Polsce. Układ regionalny" and own calculation.

Table 2. Ranking of voivodships by value of the overall Tourism Competitiveness Index developed on the basis of eight sub-indices

\begin{tabular}{rlccc}
\hline \multicolumn{1}{c}{ Voivodship } & Rank & $\begin{array}{c}\text { Tourism } \\
\text { infrastructure }\end{array}$ & Tourist traffic \\
\hline 1 & Małopolskie - Małopolska Province & 1 & 4 & 1 \\
2 & Mazowieckie - Mazovia Province & 2 & 1 & 2 \\
3 & Pomorskie - Pomerania Province & 3 & 2 & 3 \\
4 & Dolnośląskie - Lower Silesia Province & 4 & 5 & 4 \\
5 & Zachodniopomorskie - West Pomerania Province & 5 & 5 & 5 \\
6 & Śląskie - Silesia Province & 6 & 3 & 6 \\
7 & Wielkopolskie - Wielkopolska Province & 6 & 7 & 6 \\
8 & Podkarpackie - Podkarpacie Province & 8 & 11 & 8 \\
9 & Lubelskie - Lublin Province & 9 & 10 & 9 \\
10 & Kujawsko-pomorskie - Kujawy-Pomerania Province & 10 & 9 & 10 \\
11 & Lubuskie - Lubuskie Province & 10 & 8 & 10 \\
12 & Warmińsko-mazurskie - Warmia-Masuria Province & 12 & 11 & 12 \\
13 & Lódzkie - Łódź Province & 13 & 14 & 13 \\
14 & Podlaskie - Podlasie Province & 13 & 13 & 13 \\
15 & Świętokrzyskie - Świętokrzyskie Province & 13 & 15 & 13 \\
16 & Opolskie - Opole Province & 16 & 16 & 16 \\
\hline
\end{tabular}

Source: "Turystyka w Polsce. Układ regionalny" and own calculation. 
To make joint ranking of voivodships we may use eight ranks of sub-indices. The results obtained are presented in Table 2.

\section{Conclusions}

The system of creating standardised indices is a widely recognised tool for preparing various rankings, mostly for assessing the positions of entities covered and for comparing changes observed in subsequent years.

Gathering information constituting a specific set of indicators included in the overall tourism index allows to carry out a number of comparisons and assessments of positions and of reasons for specific positions on the tourism competitiveness map. In addition, a comprehensive set of indicators also facilitates identifying the causes of an increased or decreased competitiveness of a country or region in the ranking.

The analysis of the ranks obtained in the Travel \& Tourism Competitiveness Index ranking by Poland and its competitors, contained in the document entitled "The Marketing Strategy of Poland in the Tourism Sector for 2012-2020" (Marketingowa strategia..., 2011), prepared by the Polish Tourist Organisation, can be used as the basis for selecting indices to be improved as a matter of priority in order to simultaneously enhance Poland's position in the ranking and to move ahead of specific countries.

Improving the place of Poland in the ranking was defined as one of the main indicators of the attainment of the marketing strategy objectives.

A similar - even if somewhat simplified - role in assessing the tourism sector and tourism-oriented activities of the regional administration authorities in voivodships is played by comparisons of values of individual indicators across voivodships. Evidently, regional governments attach greater importance to changes in the index values in specific years and to improving the position of the voivodship concerned in the ranking. The choice of the main indicators to be observed also reflects the priorities adopted in the tourism policy of the voivodship in question.

\section{References}

Annoni, P., Dijkstra, L. Gargano, N. (2017). The EU Regional Competitiveness Index 2016. Working Papers no 2/217. Luxembourg: European Commission for Regional and Urban Policy.

Boguszewski, P. (2016). Globalny raport konkurencyjności 2016-2017 Światowego Forum Gospodarczego. Narodowy Bank Polski.

Borne-Januła, H., Byszewska-Dawidek, M., Kulesza, I., Legienis, H., Radkowska, B (2003). Turystyka Polska w 2002 roku. Układ regionalny. Warszawa: The Institute of Tourism for the Ministry of Economy, Labour and Social Policy.

Dwyer, L., Mellor, R., Livaic, Z., Edwards, D., Kim, Ch. (2004). Attributes of destination competitiveness: A factor analysis. Tourism Analysis, 9. Cognizant Comm. Corp.

Góralski, P., Lazarek, M. (2009). Czynniki kształtujące konkurencyjność regionów. Zeszyty Naukowe SGGW w Warszawie. Polityki Europejskie, Finanse i Marketing, 1 (50), 307-315.

Konkurencyjność regionów turystycznych (2014). Przedsiębiorczość i zarządzanie, 4 (XV), cz. 3.

Krugman, P. (1996). Making sense of the competitiveness debate. Oxford Review of Economic Policy, 3 (12), 17-25.

Marketingowa strategia Polski w sektorze turystyki na lata 2012-2020 (2011). Prepared by the Polish Tourist Organisation.

Morrison, D.F. (2005). Multivariate Statistical Methods. New York, NY, USA: McGraw-Hill.

Nawrot, Ł., Zmyślony, P. (2009). Międzynarodowa konkurencyjność regionu turystycznego. Od programowania rozwoju do zarządzania strategicznego, Kraków: Proksenia.

Radkowska, B. (2003-2012), Turystyka Polska w 2003 roku. Wielkie miasta. Warszawa: Instytut Turystyki.

Radkowska, B. (2004-2012). Turystyka Polska w 2003 roku. Układ regionalny. Warszawa: Instytut Turystyki.

Radkowska, B. (2013-2014). Turystyka Polska w 2013 roku. Wielkie miasta. Warszawa: Instytut Turystyki SGTiR. 
Radkowska, B., Łopaciński, K. (2013-2015) Turystyka Polska w 2013 roku. Układ regionalny. Warszawa: Instytut Turystyki SGTiR. Schwab, K. (ed.) (2015). The Global Competitiveness Report 2015-2016. Geneva: World Economic Forum.

The Travel \& Tourism Competitiveness Report 2015. Growth through Shocks (2015). Geneva: World Economic Forum.

Winiarski, B. (1999). Czynniki konkurencyjności regionów. In: M. Klamut (ed.), Konkurencyjność regionów (pp. 50-51). Wrocław: AE im. Oskara Langego.

Cite this apticle aS: Radkowska, B., Łopaciński, K. (2017). Conditions of tourism development in Polish voivodships. European Journal of Service Management, 3 (23), 53-61. DOI: 10.18276/ejsm.2017.23-07. 